\title{
Kajian Penggunaan Media Pembelajaran dalam Pelatihan Peningkatan Kompetensi Profesional Guru
}

\author{
Mashoedah, SPd., MT \\ Pendidikan Teknik Elektronika Fakultas Teknik \\ Universitas Negeri Yogyakarta \\ mashoedah@uny.ac.id
}

\begin{abstract}
ABSTRAK
Tujuan dari makalah ini adalah mengkaji penggunaan media pembelajaran untuk pelatihan guru. Jenis Media pembelajaran yang bagaimana yang dapat digunakan dalam pelatihan guru untuk meningkatkan kompetensi profesional guru. Metode yang digunakan adalah studi pustaka dan online survei kepada guru yang berada di grup guru di jejaring sosial media. Penggunaan metode survei online di grup guru di jejaring sosial media diharapkan dapat menggali respon guru terhadap penggunaan media pembelajaran yang sesuai untuk pelatihan, serta permasalahan-permasalahan lain dalam peningkatan kompetensi profesional guru. Hasil kajian dan survei yang telah dilakukan menunjukkan bahwa permasalahan yang sering dihadapi oleh guru adalah "Peningkatan kemampuan di bidang keahlian" (42\%), "Minimnya alat bantu mengajar disekolah" (24\%), "Kurikulum" (15\%) dan permasalahan lainnya (19\%). Sedangkan pendapat guru tentang penggunaan media pembelajaran pada pelatihan guru masih sangat diperlukan dan media pembelajaran yang diharapkan dalam pelatihan guru adalah dalam bentuk : gabungan media (49\%), video pembelajaran (29\%), e-learning (15\%); dan trainer kit $(6 \%)$. Alternatif model pelatihan yang diharapkan adalah pengintegrasian media pembelajaran pada pelatihan peningkatan kompetensi guru.
\end{abstract}

Kata kunci : Media, Kompetensi, Pelatihan, Pengembangan

\section{PENDAHULUAN}

Seorang guru harus memiliki kemampuan yang dipersyaratkan oleh undangundang. Kemampuan yang dimaksud adalah seperti yang telah disebutkan oleh UndangUndang Republik Indonesia tentang Guru dan Dosen no. 14 tahun 2005, pasal 8 (Undangundang, 2005) dan Peraturan Pemerintah tentang Guru Nomor 74 tahun 2008, pasal 2 (PP, 2008) bahwa "Guru wajib memiliki kualifikasi akademik, kompetensi, sertifikat pendidik, sehat jasmani dan rohani, serta memiliki kemampuan untuk mewujudkan tujuan pendidikan nasional". Disebutkan pula bahwa "Kompetensi sebagaimana dimaksud adalah merupakan seperangkat pengetahuan, keterampilan, dan perilaku yang harus dimiliki, dihayati, dikuasai, dan diaktualisasikan oleh guru dalam melaksanakan tugas keprofesionalan", yang meliputi kompetensi pedagogik, kompetensi kepribadian, kompetensi sosial, dan kompetensi profesional.
Kompetensi Profesional adalah kompetensi yang sangat penting bagi guru. Kompetensi ini memiliki bobot $70 \%$ dalam uji kompetensi guru (BPSDMP-PMP, 2012). Kompetensi profesional menurut Peraturan Pemerintah Republik Indonesia Nomor 74 Tahun 2008 adalah merupakan kemampuan Guru dalam menguasai pengetahuan bidang ilmu pengetahuan, teknologi, dan/atau seni dan budaya yang diampunya yang sekurangkurangnya meliputi penguasaan:

[Grab your reader's attention with a great quote from the document or use this space to emphasize a key point. To place this text box anywhere on the page, just drag it.]

1. materi pelajaran secara luas dan mendalam sesuai dengan standar isi program satuan pendidikan, mata pelajaran, dan/atau kelompok mata pelajaran yang akan diampu; dan 
2. konsep dan metode disiplin keilmuan, teknologi, atau seni yang relevan, yang secara konseptual menaungi atau koheren dengan program satuan pendidikan, mata pelajaran, dan/atau kelompok mata pelajaran yang akan diampu.

Profesionalisme guru atau kompetensi profesional guru menjadi bahan perdebatan dan menjadi isu sentral di media cetak dan elektronik ketika hasil uji kompetensi menunjukkan hasil yang rendah. Hasil uji kompetensi ini merupakan salah satu syarat pemberian sertifikat pendidik kepada guru. Melalui uji kompetensi, guru diuji dan dinilai kegiatan yang sudah dikerjakan selama ini dalam bidangnya. Hasil uji kompetensi guru menunjukkan hasil yang tidak memuaskan dan sangat memperihatinkan (Ihsan, 2012) (Zubaidah, 2012), hasil ini disebabkan karena guru tidak menguasai mata pelajaran yang diampunya. Nilai rata-rata guru mata pelajaran berkisar di angka 18-23. Kompetensi guru secara nasional mempunyai rerata untuk guru Taman Kanak-kanak $(58,87)$, guru Sekolah Dasar $(36,86)$, Guru Sekolah Menengah Pertama (46,15), guru Sekolah Menengah Atas $(51,35)$, guru Sekolah Menengah Kejuruan $(50,02)$ serta untuk pengawas $(32,58)$ (Napitupulu, 2012).

Masih rendahnya kompetensi guru juga terungkap dengan adanya sekitar 4,94\% guru tak lulus Uji Kompetensi Awal (UKA) (Ihsan, 2012). Hasil UKA yang rendah ini merupakan cermin dari realitas guru yang tidak pernah mendapatkan pembinaan dan pelatihan dari pemerintah (Akuntono, 2012). Apakah benar guru tidak pernah mendapat pelatihan ? Jawabannya adalah tidak benar, jikalau guru tidak pernah mendapat pelatihan, yang benar adalah bahwa belum meratanya kegiatan pelatihan kepada guru, ketersediaan dana untuk penyelenggaraan pelatihan, jenis dan bidang pelatihan yang belum sesuai dengan bidang keahlian guru, model pelatihan, keengganan guru mengikuti pelatihan, rendahnya motivasi guru untuk mengikuti pelatihan, dan masih minimnya penggunaan media pembelajaran dalam pelatihan.

Rendahnya nilai uji kompetensi awal memang belum bisa dijadikan patokan sebagai alat ukur tinggi rendahnya profesionalitas guru. Namun dari hasil uji kompetensi tersebut menunjukkan adanya permasalahan dalam peningkatan kompetensi guru, baik permasalahan peningkatan kompetensi pedagogis maupun permasalahan peningkatan kompetensi profesional. Oleh karenanya langkah yang perlu dilakukan dalam peningkatan kompetensi guru adalah melalui pelatihan-pelatihan kompetensi. Salah satu kelemahan pada pelaksanaan pendidikan dan pelatihan adalah minimnya alat bantu pembelajaran atau media pembelajaran yang digunakan dalam pelatihan. Oleh karena itu keberadaan media pembelajaran akan menjadi jembatan bagi peningkatan kompetensi guru dalam pelatihan.

Sebagai batasan dalam penulisan makalah ini, maka akan dikaji penggunaan media pembelajaran dalam pelatihan untuk meningkatkan kompetensi guru dengan mengintegrasikan media pembelajaran didalamnya.

\section{METODE}

Metode yang digunakan dalam penulisan makalah ini adalah dengan melakukan studi pustaka dan survei secara online. Studi pustaka untuk mengkaji model pelatihan dan penggunaan media pembelajaran yang sesuai untuk peningkatan kompetensi profesional guru, sedangkan metode survei secara online dilakukan untuk melihat respon guru terhadap penggunaan media pembelajaran yang diinginkan serta permasalahan dalam peningkatan kompetensi profesional.

Survei Online dilakukan melalui jejaring sosial menggunakan aplikasi ask and question yang ada pada jejaring sosial Facebook (www.facebook.com). Hasil dari survey kemudian dianalisis secara deskriptif. Responden dari survei online ini adalah semua 
guru dalam grup Ikatan Guru Indonesia (IGI) di jejaring sosial facebook yang terdiri dari Guru TK (4\%), Guru SD (13\%), Guru SMP
(42\%), Guru SMA (15\%), Guru SMK (21\%), dan guru level pendidikan lainnya (5\%).

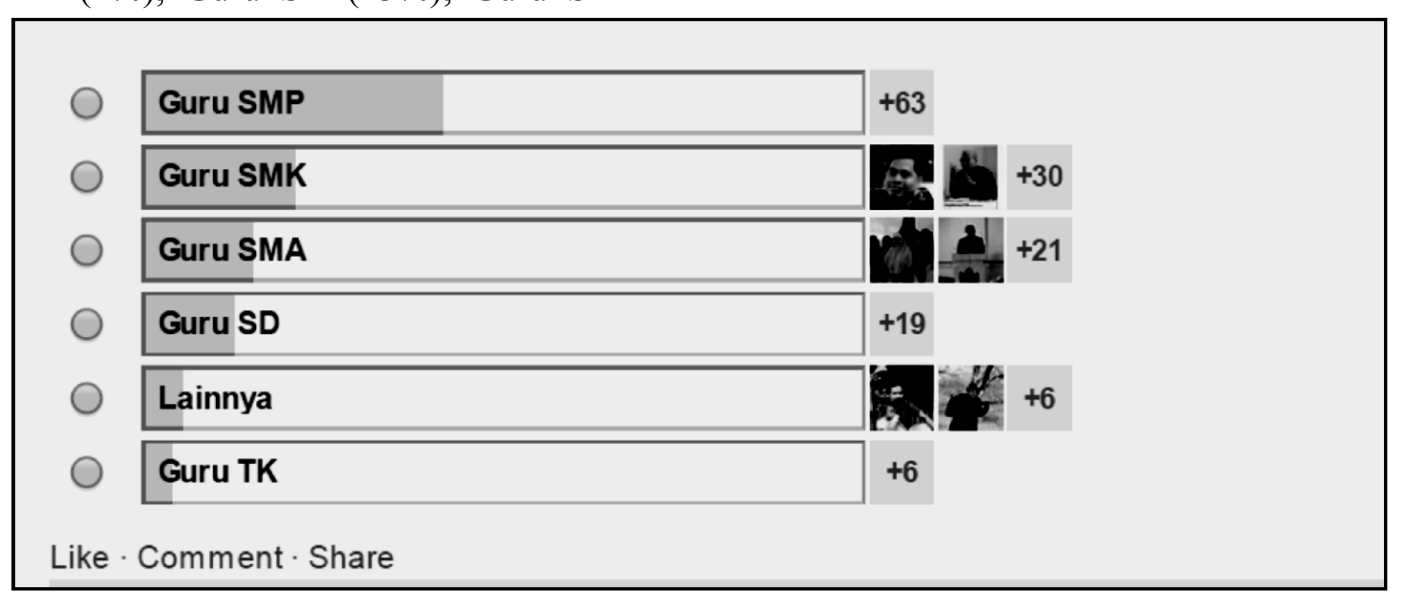

Gambar 1. Level Pendidikan tempat Responden Survei Mengajar

\section{HASIL DAN PEMBAHASAN}

\section{Permasalahan guru dan Peningkatan Kompetensi}

Guru sebagai bagian dari mahluk sosial dengan jabatan profesional menemui banyak tantangan terhadap perkembangan ilmu. Sebagai agen pengetahuan dan pendidik yang ikut andil dalam pembentukan kepribadian seseorang, guru dihadapkan pada tantangan untuk selalu meng-update pengetahuan yang ia miliki. Hambatan-hambatan waktu, dana dan kesempatan adalah alasan klasik guru untuk mengembangkan kemampuan di bidang ilmu yang ia geluti.

Disamping itu dilematik permasalahan guru adalah adanya tarik ulur antara peningkatan kesejahteraan guru (gaji) dan peningkatan kemampuan guru dalam bidangnya. Pemerintah berharap guru dapat meningkatkan kompetensinya secara mandiri seiring dengan dengan peningkatan kesejahteraan yang akan diperoleh guru, disisi lain masih banyak guru yang belum memperoleh tingkat kesejahteraan yang diinginkan sehingga harus menggeluti profesi lain dan tidak fokus pada bidang kerja profesi guru, sehingga hal ini bisa menjadi salah satu sebab rendahnya kompetensi guru. Surya (2004) menyebutkan bahwa "kinerja pendidikan yang efektif hanya mungkin terwujud ketika para guru mendapat peluang untuk memberdayakan dirinya dalam nuansa paradigma pendidikan......" (Surya, 2004).

Dilematik untuk meningkatkan kompetensi menjadi permasalahan besar bagi guru dibanding dengan permasalahanpermasalahan lain yang dihadapi guru. Seperti yang ditunjukkan oleh survei berikut ini bahwa permasalahan yang sering dihadapi oleh guru adalah "Peningkatan kemampuan di bidang keahlian" (42\%), "Minimnya alat bantu mengajar di sekolah" (24 \%), "Kurikulum" (15\%), "Kompetensi Pedagogik perlu diasah" (8\%), "Gaji" (5\%), "Pelatihan dan diklat hanya teoritis" (3\%) dan permasalahan-permasalahan yang lain yang dihadapi guru (3\%). 


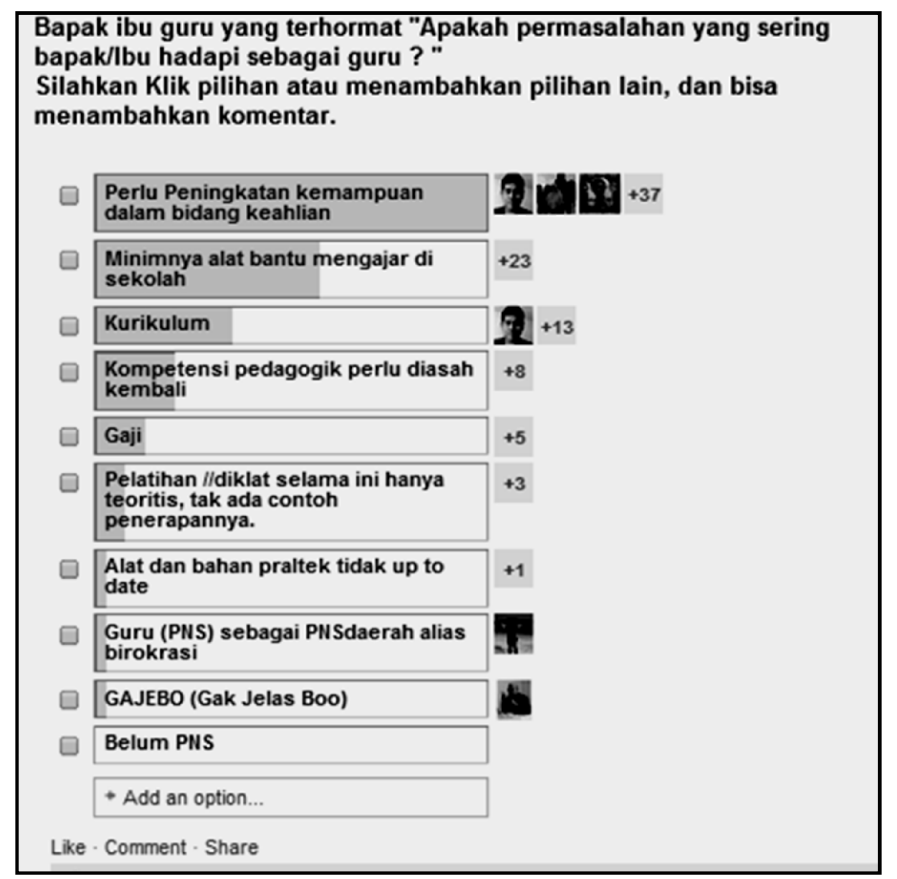

Gambar 2. Hasil Survey tentang permasalahan yang dihadapi Guru.

\section{Model Pelatihan dan Penggunaan Media Pembelajaran}

Pelatihan guru sebagai sebuah program yang bertujuan meningkatkan kompetensi profesional dan kompetensi pedagogik, harus dijalankan secara berkelanjutan, dan dikembangkan untuk mendapatkan modelmodel pelatihan yang dapat mengajak dan menginspirasi guru untuk meningkatkan kompetensi mereka secara mandiri.

Mustofa Kamil (2010) menyebutkan ada beberapa model dalam pelatihan : 1) model induktif, model ini diawali dengan mengukur kemampuan peserta pelatihan, kemudian mengelompokkan peserta pelatihan dalam kawasan program pelatihan, membandingkan kemampuan peserta dengan materi pelatihan, menetapkan kesenjangan kemampuan, mengembangkan proses pelatihan, dan melaksanakan pelatihan. 2) model deduktif, dengan model ini identifikasi kebutuhan pelatihan dilakukan secara umum dengan sasaran yang luas 3) model klasik, pelatihan menyesuaikan dengan bahan ajar dan kurikulum yang telah dibuat (Kamil, 2010).

Djudju Sudjana (1993) mengembangkan model pelatihan sepuluh langkah atau dikenal dengan model pelatihan partisipatif, yang terdiri dari : 1) rekruitmen peserta latihan; yang meliputi pendaftaran dan seleksi peserta. 2) identifikasi kebutuhan, sumber, dan kemungkinan hambatan. 3) menentukan dan merumuskan tujuan pelatihan. 4) menyusun alat evaluasi awal dan evaluasi ahkir peserta. 5) menyusun urutan kegiatan pelatihan, menentukan bahan belajar, dan memilih metode dan teknik pelatihan. 6) latihan untuk pelatih. 7) melaksanakan evaluasi terhadap peserta pelatihan. 8) mengimplementasikan proses latihan. 9) melaksanakan evaluasi akhir kegiatan. 10) melaksanakan evaluasi program pelatihan. 


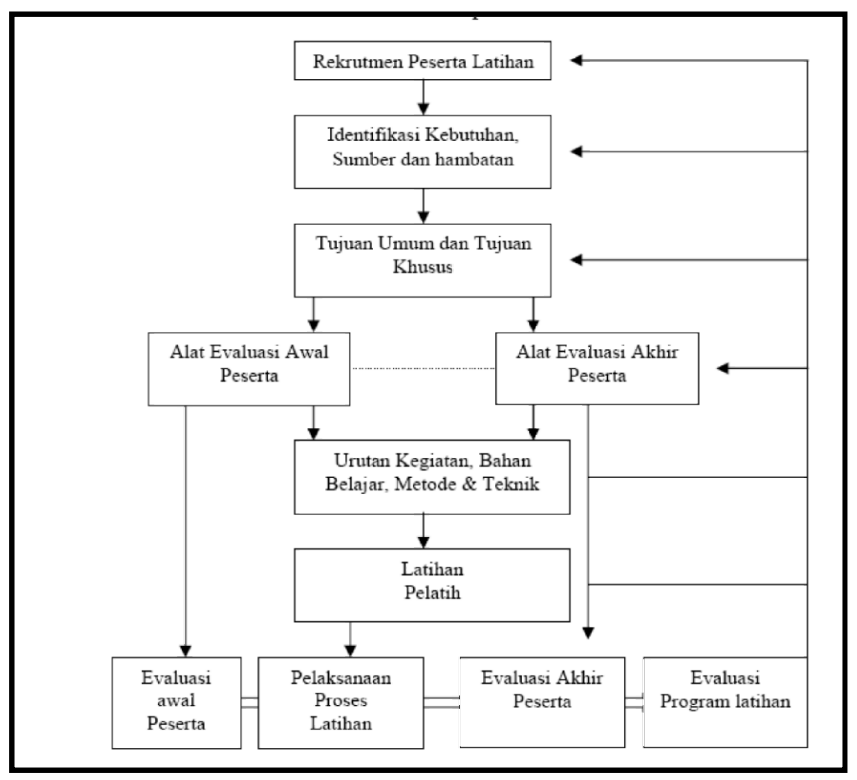

Gambar 3. Model Pelatihan Partisipatif. Djudju Sudjana (1993)

Beberapa model pelatihan tersebut diatas belum menyertakan fungsi media (Instructional Media) yang sesuai dalam pembelajaran orang dewasa untuk menginspirasi pengetahuan kepada peserta pelatihan. Beberapa Penelitian menyebutkan bahwa lingkungan pembelajaran yang memiliki Instructional Media dengan berbasis teknologi dapat meningkatkan pengetahuan dan semangat dalam belajar. Media pembelajaran juga dapat membantu untuk meningkatkan interaksi antar pengajar dan pembelajar, sehingga proses belajar mengajar akan mengarah pada Student Oriented (berpusat pada pembelajar). Dengan kata lain, penggunaan instructional media dalam bentuk audio visual, komputer, atau media-media yang lain dalam proses belajar mengajar dapat membantu pembelajar memahami materi pembelajaran.

\section{Pelatihan Guru sebagai Pembelajaran untuk Orang Dewasa}

Pembelajaran untuk orang dewasa berbeda dengan pembelajaran untuk anak-anak sekolah pada umumnya. Sebagian besar pembelajar dewasa telah memiliki tanggunggung jawab (keluarga dan pekerjaan) serta beberapa situasi yang dapat mempengaruhi proses belajar. Sebagian besar
Pembelajar dewasa memiliki motivasi yang tinggi dan berorientasi pada tugas yang ada pada dirinya. (Merriam \& Caffarella, 1999) (Cercone, 2008).

Pembelajaran orang dewasa adalah pembelajaran yang bercirikan dengan pembelajaran diikuti oleh mereka yang telah dewasa, berdasarkan situasi hidup orang dewasa, yang mempunyai fokus pada perubahan kesadaran orang dewasa (Senin, 2008). Pendidikan orang dewasa atau andragogi didefinisikan sebagai "...the art and science of helping adults to learns and the study of adult education theory, process and technology to that end" (Titmus, 1989).

Knowles menyebutkan bahwa andragogi adalah usaha untuk mengembangkan teori khusus untuk pembelajaran orang dewasa. Knowles menekankan bahwa orang dewasa yang mengarahkan diri sendiri dan berharap untuk mengambil tanggung jawab atas keputusan yang mereka ambil. Program pembelajaran orang dewasa harus mengakomodasi aspek fundamental. Asumsi Knowles tentang andragogi adalah bahwa sebagai individu dewasa, pembelajaran orang dewasa merupakan: 1) konsep diri yang berubah dari pribadi yang tergantung pada orang lain menjadi manusia mandiri; 2) 
Akumulasi dari pengalaman hidup menjadikan sumber daya yang semakin kaya untuk belajar; 3) kesiapan orang dewasa untuk belajar menjadi semakin berorientasi pada tugas perkembangan dari peran sosial yang mereka hadapi 4) orang dewasa mempunyai kecenderungan memiliki orientasi belajar yang berpusat pada pemecahan permasalahan yang dihadapi http://www.cumc.columbia.edu, 1980).

(Knowles,

Metode Andragogi ini adalah metode yang terbaik ketika diterapkan dalam situasi masyarakat dan situasi industri / perusahaan yang mendukung pembelajar secara mandiri (Crawford, 2013). Teori Belajar Adragogi dapat diterapkan apabila pembelajar adalah pribadi-pribadi yang telah dewasa, yang dapat mengarahkan diri mereka sendiri, mengerti diri sendiri, dapat mengambil keputusan untuk sesuatu yang menyangkut dirinya, dengan demikian teori andragogi ini sangatlah tepat diterapkan pada pelatihan guru.

Dalam proses belajar mengajara pendidikan orang dewasa, kegiatan dan peranan fasilitator bukanlah memindahkan pengetahuan dan keterampilan kepada peserta pelatihan, namun peran dan fungsi fasilitator adalah mendorong dan melibatkan seluruh peserta pelatihan dalam proses belajar mandiri, yaitu proses untuk memahami persoalan nyata yang dihadapi peserta, memahami kebutuhan belajarnya sendiri, dapat merumuskan tujuan, mendiagnosis kembali kebutuhan belajarnya sesuai dengan perkembangan yang terjadi dari waktu ke waktu.

\section{Penggunaan Media Pembelajaran dalam Pelatihan}

Instruksional media (media pembelajaran) tidak hanya diperlukan di proses pembelajaran tingkat sekolah (Taman Kanakkanak sampai Perguruan Tinggi), namun juga diperlukan pada proses pembelajaran pada tingkat pembelajaran yang lain seperti halnya pada pelatihan dan workshop untuk pembelajaran orang dewasa (adult learner).

Hasil survei di group guru yang dilakukan dijejaring sosial menunjukkan bahwa penggunaan media pembelajaran pada pelatihan guru masih sangat diperlukan.

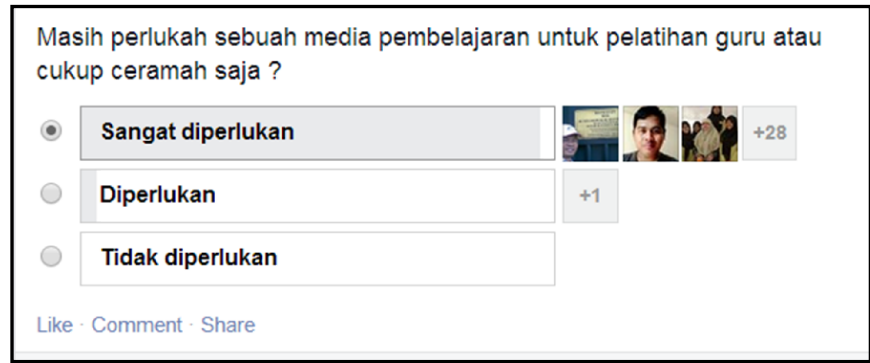

Gambar 4. Hasil Survey tentang perlu tidaknya Media Pembelajaran pada Program Pelatihan Guru.

Jenis media pembelajaran yang digunakan dalam pelatihan bisa sangat bervariasi sesuai materi dan bidang dalam pelatihan. Jenis media pembelajaran tersebut harus merujuk pada pembelajaran orang dewasa. Hasil survei menunjukkan bahwa media pembelajaran yang merupakan gabungan dari beberapa media adalah lebih disukai dari pada satu jenis media pembelajaran.
Berikut ini hasil survey di grup guru di jejaring sosial Facebook menunjukkan bahwa media pembelajaran yang diharapkan dapat digunakan di pelatihan guru adalah dalam bentuk : gabungan media (49\%), Video Pembelajaran (29\%), e-Learning (15\%); dan Trainer Kit (6\%). 


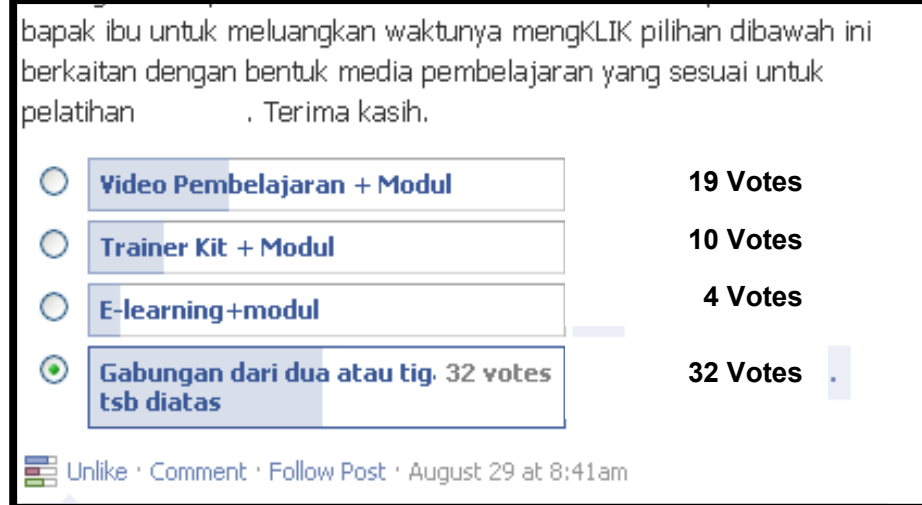

Gambar 5. Hasil Survey Penggunaan Media Pembelajaran dalam Pelatihan Guru

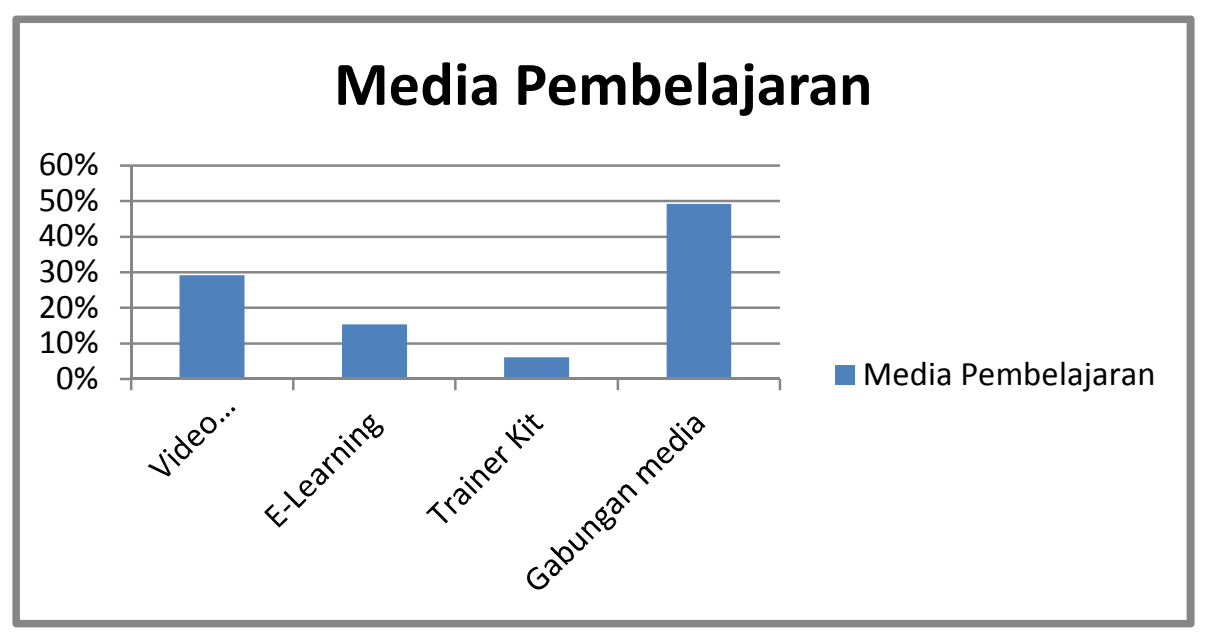

Gambar 6. Grafik Pemilihan Media Pembelajaran yang diharapkan dalam Pelatihan Guru.

Berdasar hasil survey diatas maka perlu penggunaan media pembelajaran pada pelatihan guru dan perlu dirancang sebuah model pelatihan guru yang terintegrasi dengan pemilihan media pembelajaran yang sesuai dengan materi, bidang keahlian dan gaya belajar guru (pembelajar dewasa).

\section{SIMPULAN}

a. Permasalahan yang paling sering dihadapi oleh guru adalah bagaimana guru meningkatkan kemampuan di bidang keahliannya, yang kemudian di susul dengan permasalahan minimnya alat bantu mengajar di sekolah, permasalahan kurikulum, permasalahan tentang meningkatkan kompetensi pedagogik, permasalahan gaji, permasalahan perlunya diklat/pelatihan yang memberikan contoh-contoh terapan dan beberapa permasalahan lainnya.

b. Pelaksanaan pelatihan/diklat/worshop guru sangat memerlukan media pembelajaran, agar penyampaian materi lebih mudah, contoh-contoh praktis akan mudah disampaikan dan lebih menyenangkan.

c. Bentuk media pembelajaran yang di harapkan digunakan pada pelatihan guru adalah $49 \%$ Guru memilih media dalam bentuk gabungan dari beberapa bentuk media, 29\% guru memilih video pembelajaran yang disertai modul pembelajaran, $15 \%$ guru memilih media dalam bentuk Trainer kit disertai modul, dan $6 \%$ guru memilih media dalam bentuk e-learning. 


\section{DAFTAR RUJUKAN}

Akuntono, I. (2012, Maret 17). Edukasi. (B. N. Joewono, Editor) Retrieved Maret 31, 2014, from http://edukasi.kompas.com/:

http://edukasi.kompas.com/read/2012 /03/17/07592481/sitemap.html

Akuntono, I. (2013, Maret 16). Edukasi. Retrieved Maret 27, 2014, from http://edukasi.kompas.com: http://edukasi.kompas.com/read/2012 /03/16/17455390/Ratarata.Hasil.Uji.Kompetensi.Guru.Masi h.Rendah

BPSDMP-PMP. (2012). Retrieved Maret 2014 from http://sertifikasiguru.unm.ac.id/: http://sertifikasiguru.unm.ac.id/UKA $\% 202012 /$ Bahan\%20Presentasi\%20U KA.pdf

Cercone, K. (2008). Characteristics of adult learners with implications for online learning design. AACE journal, 16(2), 137-159.

Crawford, S. R. (2013, July 23). ED205: Adult Learning. Retrieved April 9, 2014, from http://academic.regis.edu: http://academic.regis.edu/ed205/Kno wles.pdf

Ihsan, A. (2012, Maret 18). Uji Kompetensi Guru. Retrieved Maret 31, 2014, from

http://www.ujikompetensiguru.com/2 012/03/update-pengumuman-ujikompetensi-guru.html: http://www.ujikompetensiguru.com/2 012/03/update-pengumuman-ujikompetensi-guru.html

Ihsan, A. (2012). UKA Sertifikasi Guru. Retrieved Maret 31, 2014, from http://www.ujikompetensiguru.com/: http://www.ujikompetensiguru.com/2 012/04/sekitar-494-guru-tak-lulusuji.html

Kamil, M. (2010). Model Pendidikan dan Pelatihan. (Konsep dan Aplikasi). Bandung: Alfabeta.

Knowles, M. S. (1980). Retrieved April 11, 2014, from http://www.cumc.columbia.edu: http://www.cumc.columbia.edu/dept/ medicine/hospitalists/downloads/cc4 articles/Education\%20Theory/Andr agogy.pdf

Knowles, M. S. (1980). The modern practice of adult education, revised and updated. Englewood Cliffs: Prentice Hall Regents.

Napitupulu, E. L. (2012, Juli 25). Edukasi. Retrieved Maret 31, 2014, from http://edukasi.kompas.com/:

http://edukasi.kompas.com/read/2012 /07/25/19413379/Kompetensi.Guru. Memprihatinkan

PP, R. I. (2008). Peraturan Pemerintah tentang Guru Nomor 74 tahun 2008, pasal 2. Jakarta.

Senin, A. (2008). Pembangunan profesional guru. Kuala Lumpur: Utusan Publications.

Surya, M. (2004). Bunga rampai guru dan pendidikan. Jakarta: PT. Balai Pustaka.

Titmus, C. J. (1989). Lifelong education for adults. Pergamon Press.

Undang-undang, R. (2005). Undang undang Republik Indonesia Nomor 14 Tahun 2005 Tentang Guru dan Dosen. Jakarta: Departemen Pendidikan Nasional.

Zubaidah, N. (2012, Agustus 3). SOSIAL \& $B U D A Y A$. Retrieved Maret 31, 2014, 
from http://nasional.sindonews.com:

012/08/03/15/662873/hasil-uji-

$\mathrm{http}: / /$ nasional.sindonews.com/read/2

kompetensi-guru-memprihatinkan 